\title{
The Long Prison Journey of Leslie Van Houten: Life Beyond the Cult By Karlene Faith \\ Boston: Northeastern University Press (2001), 216 pp. \\ Reviewed by Liz Elliott
}

$\mathrm{n}$ the last year of the 1960 s, a decade of anomie, the U.S. experienced two millennium. These events took place at opposite sides of the country, although they occurred less than a week apart. One event, a cultural festival of music and arts, has remained in time as an example of the possibilities of peaceful coexistence in adverse circumstances of large numbers of people. From August $15^{\text {th }}$ to the $17^{\text {th }}$ the Woodstock Music and Arts Festival's patrons endured rain and mud - and all of the other inconveniences that would reasonably accrue in a situation where unexpected large numbers of people converged in one location - to see some of the decade's masters of rock and roll and folk music perform in the state of New York. Almost half a million people, many of whom were experiencing the event under the influence of various illicit drugs, attended Woodstock and lived together peacefully for one weekend. ${ }^{1}$

Across the continent a few days earlier, the world heard the news of two terrible sets of murders in California that shook the sense of security that until then was enjoyed by Americans. We were soon to learn that these bizarre, seemingly ritualistic killings were the bidding of a charismatic but crazy man. who was state-raised ${ }^{2}$ and resourceful. In this case the drugs were used to weaken the already fragile resolve of young idealistic people who were searching for themselves and open to new ways of seeing the world. Charles Manson seemed to them like a prophet, and his will a divine intervention. Among his followers, Manson saw the young women as especially vulnerable. In an interview with two contributing editors to the Rolling Stone magazine in 1970, Manson stated:

1 For a brief history and overview of Woodstock specifics, see http://Www.geocities.com/ beatlefreak1/

2. This term was used by Jack Henry Abbott to describe himself and certain fellow prisoners, as people who grew up under the "care" of social workers in foster and group homes and later punitive detention facilities. See In the Belly of the Beast (1982), New York: Vintage Books. 
In the end, the girls would be just dying to do something for me. I'd ask one of them to make a shirt for me, and she'd be just thrilled because she could do something for me. They'll work twenty-four hours a day if you give them something to do.

I can get along with girls, they give up easier. I can make love to them. Man has this ego thing. I can't make love to that. Girls break down easier. ${ }^{3}$

The ingredients were assembled; the recipe for disaster was complete. Manson had managed to turn the same focus of peace and music into a call for murder. His disciples were set to carry out the deeds that were to change the lives of many people forever.

Karlene Faith was to later encounter the young women of Manson's "family" in the California Institution for Women, when she was asked to tutor them by the prison's warden in 1972 . Thirty years later, she has remained in contact with the women who were segregated in the Special Security Unit in those early days. The Long Prison Journey of Leslie Van Houten is Faith's account of one of these women's lives.

Leslie Van Houten has been incarcerated for 33 years. Faith unfolds the story of a life that began in circumstances much different than that of Manson's, but which was to ultimately share his fate. Her account is informed by her own relationship with Leslie, and by the words of Leslie's family, friends, prison staff, lawyers, and the sentiments of those she harmed by her participation in the killings of Rosemary and Leno LaBianca. Despite Leslie's reputation as a person who has taken responsibility for her role in the crime and as a prisoner who makes herself useful to others during her incarceration, attempts for parole have been unsuccessful.

The crime at the center of Leslie's life, however, is not sidestepped in this biography. Part of the subject's journey is a venture through the California court system, and the three trials over 10 years that would establish the legal careers of prosecutors Vincent Bugliosi and Stephen Kay. Ambivalence over Leslie's role in the sensationalized killings ordered by Manson was expressed

3 Taken from an interview with and article on Charles Manson by David Felton and David Dalton, "Year of the Fork, Night of the Hunter," Rolling Stone, June 1970. Reprinted in 20 Years of Rolling Stone: What a Long Strange Trip It's Been (1987), edited by Jann S.

Wenner. New York: Friendly Press Inc, pp. 57-72. 
in the hung jury at the second trial. Yet we are not shielded from the horror of the crime itself. In her account of these trials, Faith has carefully woven her obvious affection and concern for Van Houten, the friend, with the evidence demonstrating her role in the crime. Faith's focus, as the book's subtitle would suggest, is on the brainwashing of Manson's followers and how this control plays into Leslie's own perception of her actions as she gradually reclaims her personhood over the three trials.

The Long Prison Journey of Leslie Van Houten is a meticulous account of one aspect of the Manson killings that has not been publicly considered. In the context of a tenaciously retributive justice system, Van Houten continues to willingly atone for her role in the actual killing of the LaBiancas. Faith uses court transcripts and evidence to clarify the depth of that role (Van Houten was a relatively minor player), while detailing the specifics of the cult life that made it possible for several young idealistic people to commit terrible acts that were to later horrify even them. The book offers a different perspective on the Manson case by telling the story of one person's life, a woman who has spent her adult years in prison for her participation in a crime committed at nineteen years of age, having "given up" to the manipulations of a madman.

Faith is careful not to diminish the pain and horror of the victims and their families in her account. She does not attempt to downplay the crimes, or the lasting impact they have had on the surviving families. But Faith does call us to question the very nature of punishment itself as a reflexive response to any crime. How much time could possibly be served in order to compensate for the loss of a life? The question almost seems obscene, for any number suggested might seem to set a limit on the value of the person lost. The reader gets the sense that the healing of the victims of Manson and his disciples is a problem that is separate from the practice of punishing the culprits. Leslie Van Houten does not pose a risk to public safety, has accepted responsibility for her role in the crime since the beginning of this saga, has demonstrated to everyone who knows her in prison and on the street that she is a caring and responsible person, and has devoted her life in service of others. What more can she do without the powers to turn back the clock - to make things right?

Van Houten's story, in the author's perspective, could be anyone's story. Parents and teachers of youth and young adults might see their own in the pages of this book. But in a larger sense, this story can also be seen as a symbol of American culture over the past 30 years. The lessons of peace invoked by the Woodstock experience have long since faded, having been 
replaced by a commercialization and commodification of the festival that once symbolized the hope of the sixties. Likewise, the important lessons of the Manson killings have also been missed; where American culture could have been elevated by the hope of redemption and forgiveness, it remains mired in the blackness of anger and unrelenting retribution.

In April of this year San Bernardino Superior Court Judge Bob Krug admonished the California parole board for its routine refusals of Van Houten's release over the years based only on the crime, noting that the board had not considered her accomplishments while in prison. However, in her most recent appearance before the parole board in late June, 2002 - her fourteenth appearance in 33 years of incarceration - Van Houten was again denied parole.

Liz Elliot is an assistant professor at Simon Fraser University and the CoEditor of the Journal of Prisoners on Prisons. She can be contacted at the School of Criminology, Simon Fraser University, 8888 University Drive, Burnaby, British Columbia, Canada V5A IS6. 